\title{
MENTAL HEALTH OF REFUGEES, ASYLUM SEEKERS AND MIGRANTS - AN OVERVIEW OF CHALLENGES AND GOOD PRACTICE EXAMPLES
}

\author{
Bojana Pejuskovic ${ }^{1,2}$, Maša Vukčević Markovićc M̌,,5 $^{3,5}$
}

\author{
${ }^{1}$ School of Medicine, University of Belgrade, Belgrade, Serbia \\ ${ }^{2}$ Institute of Mental Health, Belgrade, Serbia \\ ${ }^{3}$ Faculty of Philosophy, University of Belgrade \\ ${ }^{4}$ Laboratory for the Research of Individual Differences, \\ Faculty of Philosophy, University of Belgrade \\ ${ }^{5}$ Psychosocial Innovation Network, Belgrade, Serbia
}

\begin{abstract}
In the past few years the number of refugees, migrants and asylum seekers worldwide has increased dramatically. Serbia, as a mainly transit country currently hosts over 6,000 new asylum-seekers and refugees, over 26.200 refugees and 198.500 internally displaced persons from the ex-Yugoslavia region, and 1.950 persons at risk of statelessness. Migrants are often under acute and chronic stress. Many of them were traumatized in their homelands and during their journey, due to persecution, violence, and human right violations, and they are confronted with ongoing stressors in the exile countries. Extensive research has shown increased rates and substantial variability in the prevalence of short-term and long-term mental health problems among refugees, asylum seekers and migrants. The most prevalent psychiatric disorders are depression, anxiety, prolonged grief, somatoform disorders, psychosis, substance use disorders, and disorders specifically related to stress, particularly posttraumatic stress disorder. It's urgent to offer a systemic and sustainable solutions for mental health protection, in order to reduce trauma related mental health problems and prevent long-term consequences. Multisectoral, evidence-based and multidisciplinary approach is recognized as crucial in identifying needs of these populations and enabling proper protection of their mental health and psychosocial wellbeing.
\end{abstract}

Key words: migrants, refugees, asylum seekers, stress, trauma, mental health, protection 


\section{Book of Migration}

Through the time, whole planet is populated because of a human migration. This universal phenomenon - migration, has occurred in all nations at all times and means changing the location of residence. A highly heterogeneous process of migration is based on a variety of reasons. They can be voluntary's nature, involving search for better education, employment, family reunion, or various personal or professional reasons. Migrations, as well, can be involuntary, and can happen due to a war, fear of persecution, human rights violations, etc. Forced migration often happens suddenly, and has its special characteristics and consequences [1,2]. Depending on the type of migration, it is important to understand and acknowledge the difference between refugees, asylum seekers and migrants, because of its legal implications but also implications for mental health risks. Migrants choose to move voluntary for various of personal reasons, while Refugees, by its definitions, are persons forcibly fleeing armed conflict or persecution, and they are recognized as persons in need for international protection because it is too dangerous for them to return home. Asylum seeker is an individual who is seeking international protection due to fear of persecution, and based on an outcome of asylum procedure it is decided whether international protection will be granted or not. Therefore, not every asylum seeker will ultimately be recognized as a refugee, bud every recognized refugee was initially an asylum seeker $[3,4]$.

Worldwide, around 70.8 million people are forcibly displaced because of wars, conflicts, persecutions, and human rights violations, including 41.3 million internally displaced persons, 25.9 million of refugees, 3.5 million asylum seekers, while 50\% of them are children [5]. During 2016, 347.000 refugees and migrants have arrived in Europe, in addition to the over one million refugees and migrants that undertook the perilous journey across the Mediterranean Sea in 2015, and a further 34.000 crossing from Turkey into Bulgaria and Greece by land [6].

Current refugee, migrant and asylum seeker crisis - Serbian situation

The number of arrivals of refugees, asylum seekers and migrants in Serbia increased dramatically during 2015, up to around $2.500-3.000$ persons per day, putting severe pressure on the existing reception capacities in the country [7]. Data suggests that $85 \%$ of the 2016 population of migrants and refugees in Serbia originated from refugee producing countries, including $61 \%$ women and children and 39\% adult men [8]. A significant portion of the population included additionally vulnerable groups such as unaccompanied minors, families with children, pregnant women, and the elderly persons. The socioeconomic characteristics of migrants and refugees in Serbia are varying over time. The demographics changes since 2015 reflect changes in international political affairs; for example, in 2015: 50-60\% of the migrants and refugees were from Syria [8], while in December 2019, 46\% of 1,713 newly arriving asylum seekers and migrants came from Afghanistan and almost a third 
from Syria and Iraq. According to UNHCR Serbia update, in 2018 new arrivals of refugees are increasing from January to May 2018 with the total number of 16.165 in 2018 [5]. This total number of new arrivals encountered in 2019 is 30,216 (almost doubled when comparing to the number of arrivals in 2018). The newest update from the UNHCR Serbia Fact Sheet by January 2020, indicates that Serbia hosts over 6,000 new asylum-seekers and refugees, over 26.200 refugees and 198.500 internally displaced persons from the ex-Yugoslavia region, and 1,950 persons at risk of statelessness [9].

\section{Stress, trauma and migration}

Migration itself is a very complex phenomenon and the ones involved in migration usually go through a stages of adjustment while responding to a number of stressors related to the preparation, migration itself, and post migration adjustment [10]. Commonly, those stress factors are categorized as premigration - such as persecution, economic hardship; perimigration - such as separation, physical danger, life-threatening conditions; and postmigration - including uncertainty, reduced social integration, discrimination, etc. [11]. Numerous studies demonstrated negative effects these stages can have on refugees', asylum seekers' and migrants' mental health and wellbeing [12,13]. In addition, there is a growing body of evidence postmigration factors are of particular importance of for psychological wellbeing [14-16], indicating that postmigration risk factors are critical to whether the diagnosed mental health disorder will become chronic or not $[17,18]$.

Due to these contextual factors, refugees, asylum seekers and migrants are often under acute and chronic stress. In addition, some of them were traumatized by a wide range of different acts of violence and human right violations in their homelands, as well as during their journey, and they are confronted with ongoing stressors in the countries they are currently live in [1921]. As a result, they could experience variety of symptoms - anxiety, depression, intensive fear, worries, startle reaction or anger, they could feel emotional numbing or detachment, sleep disturbances or nightmares [2]. In addition, they could feel overwhelmed or confused, mostly affected by multiple losses, or grieving for people or home, which they left behind. Apart from the loss of belongings, friends, family and possessions, refugees, asylum seekers and migrants may also experience sense of loss of belonging [22]. Furthermore, migration is associated with specific stressors, such as process of acculturation which occurs during adaptation to the host country [23]. Some authors stressed that arrival in the new country, with a new culture, new values and structures, may produce experience of a "culture chock" and its response might be both positive and negative [24]. Culture shock may cause negative emotions such as dysphoria or sense of detachment, which may further lead to poor self-esteem, negatively influence process of integration, and may affect appropriate acculturation $[22,25]$. Berry (2007) suggests the term `acculturative stress', 
because each of these stress experiences can be managed by strategies which individuals can use in adaptation to the new circumstances [26]. Furthermore, studies have showed that difficulty trusting others and increased perceptions of hostility are common phenomena in refugee and migrants from conflict affected regions [27]. In conflict-affected settings, where misplaced trust may have catastrophic consequences, sensitivity to potential threat may remain high, even when there is no longer imminent danger. This heightened sensitivity may be unnecessary or even contribute to psychological distress, as evidenced by findings linking interpersonal sensitivity and psychological symptoms [28]. Nickerson and collaborators [29] have pointed out that interpersonal sensitivity mediates the relationship between war trauma exposure and anger reactions, which could happen more frequent amongst war survivors and refugees [30].

It should, however, be noted that vast majority of previous studies and available literature on migration were focused mainly on negative aspects migration can have on mental health and wellbeing, and that more evidence is needed, including longitudinal studies and the ones exploring potentials for psychological growth and resilience migration can offer, in order to be able to comprehensively understand effects migration could have on one's mental health and wellbeing.

\section{Mental health of refugees, asylum-seekers and migrants}

There are numerous ethical and methodological issues in assessing refugees', asylum seekers' and migrants' mental health [31] which could be one of the reasons for inconsistent results of previous studies. In addition, it should be noted that there is a lack of studies exploring positive aspects of psychological functioning among refugees, which can influence biased perception of their resilience and vulnerability, leading to pathologization, stigmatization and misconceptions on refugees', asylum seekers' and migrants' mental health. It should, therefore, be noted again that being a refugee, asylum seeker or a migrant does not, by itself, make individuals significantly more vulnerable for mental disorders, but refugees, asylum seekers and migrants can be exposed to various stress factors that can influence their mental health and wellbeing [32]. In addition, the exposure of refugees and migrants to the risks associated with population movements - psychosocial disorders, drug abuse, nutrition disorders, alcoholism and exposure to violence - increase their overall vulnerability to noncommunicable diseases (NCDs). The key issue with regard to NCDs is the interruption of care, due either to lack of access or to the decimation of health care systems and providers, and displacement resulting in interruption of the continuous treatment that is crucial for chronic conditions [33].

Extensive research showed increased rates and substantial variability in the prevalence of short-term and long-term mental health problems among refugees, asylum seekers and migrants [34]. In comparison with the general population, they have been shown to experience higher prevalence rates of a 
range of mental disorders $[18,35,36]$. The most prevalent are depression, anxiety, somatoform disorders, psychosis, substance use disorders, and disorders specifically related to stress, particularly posttraumatic stress disorder $[17,34,36]$. Prolonged grief in refugees exposed to trauma and loss has been reported in approximately $10 \%$ of bereaved individuals [37]. Bearing in mind protective and risk factors for PTSD [38], including sociodemographic characteristics [39,40], psychiatric comorbidity [38,41], number, severity and type of stressors [39], higher personal distress, low quality of life [39], it does not come as surprise that refugees, asylum seekers and migrants represent groups under increased risk for this syndrome. Therefore, researchers have shown that PTSD is ten times more likely in refugees and asylum seekers compared to host population $[18,35,36]$, with registered prevalence of PTSD in refugees (9\%) being higher than estimates for host country population $(1-3 \%)$ [35,42]. There is evidence that prevalence of PTSD is higher in refugees and asylum seekers, who were exposed to multiple traumatic events $[43,44]$. Furthermore, PTSD rates in irregular migrants seem to be lower (3\%) than for other migrants and more similar to populations in the host country [11]. It should also be noted that PTSD is associated with medically unexplained somatic syndromes, such as tinnitus, dizziness, different medical conditions, such as cardiovascular, respiratory, gastrointestinal, neurological, endocrine, immune-mediated disorders [45], as well as with other mental disorders such as depression, substance abuse and somatoform disorders [2,35,46,47]. Previous studies have shown co-morbidity between PTSD and psychosis among traumatized refugees $[12,48]$, and suggested that cumulative traumatic events may be a causal factor for the later development of psychosis [49]. Moreover, in order to efficiently identify patients in need of help, it is important to recognize that signs of posttraumatic stress can vary, be delayed and include various psychiatric and somatic comorbidity.

A multicentric, international epidemiological study "CONNECT" (supported by the EU within FP6) carried out on 5.000 subjects in countries of former Yugoslavia as well as on the 854 war refugees from former Yugoslavia who were living in Germany, Italy and UK. Results of this study have shown that those people experienced on average 6.8 different traumatic war events and 2.6 migration stressors. The most frequent war-related traumatic experiences were 'shelling or bombardment' (84.9\%), 'lack of shelter' $(64.3 \%)$ and 'being under siege' (59.3\%) [17]. The most frequently experienced migrationrelated stressors were 'inadequate accommodation' (52.9\%), 'separation from family for a long time' (52.3\%) and 'financial difficulties' (52.2\%). Participants had been in exile on average 9.3 years. Between $41.8 \%$ (in Italy) and $67.9 \%$ (the UK) of refugees in each sample originated from Bosnia and Herzegovina, and each other group of origin represented less than $24 \%$ of the sample. In the total number of participants, $54.9 \%$ had at least one of the studied DSMIV disorders. Rates of anxiety disorders were $43.7 \%$ (range 30.3-60.7) and of 
mood disorders $43.4 \%$ (range 30.0-57.4). Most prevalence rates were highest in Germany and lowest in Italy. The exceptions were higher rates of major depressive episode in the UK and of generalized anxiety disorder in Italy [17].

Bogic and collaborators (18) identified 29 studies on long-term mental health problems in a total of 16,010 war-affected refugees with heterogeneous results. The prevalence rates for PTSD were in the range 4.4-86\%, for depression 2.3-80\%, and for unspecified anxiety disorder 20.3-88 \%. The prevalence estimates of most of these disorders were typically in the range of $20 \%$ and above. The prevalence rates were related to both the country of origin and the country refugees resettled in. It was shown that refugees from former Yugoslavia and Cambodia tended to report the highest rates of mental disorders, as well as refugees residing in the USA. The greater exposure to pre-migration traumatic experiences and post-migration stress were the most consistent factors associated with all three disorders - PTSD, anxiety and depression. The poor post-migration socio-economic status was particularly associated with depression [18].

Studies conducted in Serbia in period from 2015 to 2019 indicated refugees, asylum seekers and migrants coming to Serbia were exposed to numerous traumatic experiences $[19,20]$, as well as that in this period of time from 70 to $85 \%$ of refugees, asylum seekers and migrants in Serbia screened positive for mental health difficulties, i.e. symptoms of depression, anxiety, current distress and post-traumatic stress [19,50-53]. Bearing in mind that since 2015 there have been between 3500 and 125000 refugees, asylum seekers and migrants in Serbia at various time points, Serbian health care system needed to address the mental health needs for approximately $3000-10000$ refugees and migrants at any given point in time [54]. Being both transit county, but also country of destination for some of service users, in line with ethical principles, this support needed to respond to identified mental health needs, but also to be adjusted to their duration of stay, language barriers, prioritized in case of lack of resources, etc. [31].

Even though there is a lack of studies exploring positive aspects of psychological functioning among refugees, asylum seekers and migrants, recent study showed that $70.6 \%$ of refugees and asylum seekers feel optimistic about future, $77.9 \%$ believe they have the capacity to achieve great things in life, while $51 \%$ of refugees and asylum seekers feel that they have the capacities to deal with future challenges and problems [53]. These results highlight that majority of refugees have preserved strengths and coping capacities, and question whether mental health difficulties refugees, asylum seekers and migrants are facing indicate presence of mental health disorders, or rather represent expected reactions to difficulties and uncertainty they are facing on a daily basis.

\section{Additional challenges in refugees', asylum seekers' and migrants' mental health protection}

In addition to higher risks for mental health difficulties and prevalence rates for mental health disorders, there are several more challenges that need 
to be addressed when discussing comprehensive mental health care for refugees, asylum seekers and migrants. Recent studies from various countries indicated hesitation in usage of available mental health services among refugees experiencing mental health difficulties, showing that only $9 \%$ of refugees in Netherland experiencing mental health difficulties visit some of the specialized mental health institutions [55], while this number reach 20\% in Denmark $[56,57]$. These results highlight the need for identification of barriers and challenges in mental health protection even after services are being made available to refugees, asylum seekers and migrants. These challenges could include questions on accessibility, cultural specifies of these services, overall trust in institutions as well as whether information on available services and mechanisms of support are being timely and properly shared among refugee community [58]. A survey conducted among users of mental health services from the refugee community, aiming to identify mentioned challenges, indicated that refugees identified need for more activities focused on prevention of mental health disorders, especially among adult population. The question of continuity in availability of mental health services, especially in those situations when mental health services are provided by NGO sector was also identified as challenge. In addition, lack of privacy, i.e. available rooms for counselling, and the lack of professional interpreters available for these purposes was also recognized by the members of refugee community as a reason for hesitation in usage of available services. Furthermore, participants stressed out that due to fear of being stigmatized, refugees, asylum seekers and migrants could hesitate to be the ones who will initiate communication with mental health professionals [59]. It was suggested that this could be overcome with informal introductory sessions, or age and gender adjusted structured activities promoting mental health protection and initiating communication on this matters [59].

When discussing refugees' and asylum seekers' mental health, challenges in protection and risk factors, it should also be noted that asylum procedure, a required step in obtaining international protection, impose additional risks for their mental health [53]. Thus, it was shown that longer asylum procedure and the one with uncertain outcomes and delays is related to more severe psychological difficulties [16]. In addition, it was shown that hearings and interviews can lead to more prominent PTSD symptomatology [60]. Finally, in case of a negative asylum decision there is increased chance for a person to experience more pronounced symptoms of anxiety, depression and PTSD, and suicidal thoughts and intentions [61]. Some authors discussed that learning about positive decision may also impose additional mental health and well-being risks, as it opens up many questions regarding the future life [53].

Bearing in mind mentioned challenges related to both mental health needs, as well as additional contextual obstacles in provision of mental health 
protection to refugees, asylum seekers and migrants, multidisciplinary, multisectoral and evidence-based approaches are utmost needed in order to enable timely and well-adjusted mental health protection to those in need.

\section{Mental health protection during the refugee crises - good practice examples from Serbia}

Since the beginning of the latest refugee crises in Serbia, while trying to provide protection and support to those in need, several examples of good practice in ensuring and improving mental health protection for refugees, asylum seekers in migrants should be noted. With the initiative and support of the World Health Organization, in December 2018, the first comprehensive, strategic document named Guidance on Protection and Improvement of Mental Health of Refugees, Asylum Seekers, and Migrants in Serbia [62] was developed. This document defined standards in the protection of the mental health of refugees, asylum seekers, and migrants in Serbia, which were closely monitored through established mechanisms [59]. Guidance was developed by the experts from the Institute for Mental health, the Institute for Public health, nongovernmental organization PIN - Psychosocial Innovation Network and the Department of Psychology, Faculty of Philosophy, University of Belgrade, and adopted by the Ministry of Health and the Commissariat for Refugees and Migration of the Republic of Serbia.

Based on standards defined by the Guidance, numerous improvements in overall coordination of mental health protection, capacity building and availability and efficacy of mental health protections were made. Two multidisciplinary bodies aiming to improve the protection of mental health of refugees, asylum seekers and migrants were formed. The first body named the Working Group for the Protection and Improvement of Mental Health of Refugees, deals with the current challenges, develops recommendations, and monitors the implementation of the planned response and defined standards. The second body is the Task Force for Resolving Unpredicted and Urgent Situations in the Field, which gathers in the situations which deviate from defined procedures for the protection of psychologically vulnerable refugees, asylum seekers and migrants. Furthermore, psychological support was made available in vast majority of accommodation facilities for refugees; practitioners and service providers participated in capacity building trainings; supervision and continuous trainings were made available for mental health practitioners, etc. [59]. Finally, in January 2019, as a result of strengthened multidisciplinary approach, positive decisions on an application for international protection made by the Asylum Office for the first time cited a psychological report on the psychological state of the asylum seeker, and relied on psychological evaluations and recommendations related to the psychological wellbeing of the asylum seekers [53]. 


\section{Conclusion}

Migration per se, especially involuntary one, brings numerous risks which can negatively influence refugees', asylum seekers' and migrants' mental health and wellbeing. As a result of exposure to these risks, which often include violence, human right violations, risky journey, uncertainty and lack of social support, there are increased mental health difficulties among these populations. Furthermore, numerous contextual factors are putting additional burden to this matter. Experiences from some countries indicate that multisectoral and multidisciplinary approach in addressing mental health needs of refugees, asylum seekers and migrants is crucial for enabling timely, quality, adjusted and efficient mental health protection to those in need. 


\title{
MENTALNO ZDRAVLJE IZBEGLICA, TRAŽILACA AZILA I MIGRANTA - IZAZOVI I PRIMERI DOBRE PRAKSE
}

\author{
Bojana Pejuskovic ${ }^{1,2}$, Maša Vukčević Markovićc $3,4,5$ \\ ${ }^{1}$ Medicinski fakultet Univerziteta u Beogradu, Beograd, Srbija \\ ${ }^{2}$ Institut za mentalno zdravlje, Beograd, Srbija \\ ${ }^{3}$ Filozofski fakultet, Univerziteta u Beogradu \\ ${ }^{4}$ Laboratorija za istraživanja individualnih razlika \\ Filozofski fakultet, Univerziteta u Beogradu \\ ${ }^{5}$ Psihosocijalna inovativna mreža, Beograd, Srbija
}

\begin{abstract}
Apstrakt: U poslednjih nekoliko godina, broj izbeglica, migranata i tražilaca azila dramatično je porastao širom sveta. Srbija, kao glavna tranzitna zemlja, trenutno je domaćin za preko 6,000 novih tražilaca azila i izbeglica, za preko 26,200 izbeglica i 198,500 interno raseljenih lica iz regiona bivše Jugoslavije, kao i za 1,950 osoba pod rizikom od gubitka države. Migranti su često pod akutnim i hroničnim stresom. Mnogi od njih traumatizovani su u svojim domovinama i tokom puta, usled progona, nasilja, povreda ljudskim prava, i suočeni su sa stalnim stresorima u zemljama egzila. Obimna istraživanja pokazala su povećane stope i znatnu varijabilnost u prevalenciji kratkoročnih i dugoročnih problema mentalnog zdravlja među izbeglicama, tražiocima azila i migrantima. Najprevalentniji psihijatrijski poremećaji su depresija, anksioznost, prolongirano tugovanje, somatoformni poremećaji, psihoze, zloupotreba supstanci, kao i poremećaji specifično povezani sa stresom, posebno posttraumatski stresni poremećaj. Hitno je potrebno ponuditi sistematične i održive solucije za zaštitu mentalnog zdravlja, kako bi se smanjili sa traumom povezani problemi mentalnog zdravlja i prevenirale dogoročne posledice. Multisektorni, na dokazima zasnovan, multidisciplinarni pristup, prepoznat je kao krucijalni u prepoznavanju potreba ovih populacija i omogućavanju adekvatne zaštite njihovog mentalnog zdravlja i psihosocijalnog blagostanja.
\end{abstract}

Ključne reči: migranti, izbeglice, tražioci azila, stres, trauma, mentalno zdravlje, zaštita 


\section{References}

1. Lecic Tosevski D, Pejuskovic B. Refugee, Migrants and Asylum Seeker Experiences. In: Bhugra D, editor. Oxford Textbook of Migrant Psychiatry. Oxford University Press (in press).; 2018.

2. Pejuskovic B, Lecic Tosevski D, Toskovic O. Longitudinal study of PTSD and depression in a war exposed sample - comorbidity increases distress and suicide risk. Glob Psychiatry. 2020;3(1).

3. United Nations High Commissioner for Refugees [UNHCR]. UNHCR viewpoint: 'Refugee' or 'migrant' - Which is right? [Internet]. 2016. Available from: https://www.unhcr.org/news/latest/2016/7/55df0e556/unhcr-viewpoint-refugee-migrant-right.html

4. International Organization for Migration. Glossary on Migration. Genewa: Switzerland; 2019.

5. United Nations High Commissioner for Refugees [UNHCR]. Regional refugee and migrant response plan for Europe [Internet]. 2018. Available from: https://www.unhcr.org/globaltrends2018/

6. United Nations High Commissioner for Refugees [UNHCR]. Regional refugee and migrant response plan for Europe [Internet]. 2016. Available from: http://www.unhcr.org/partners/donors/589497d07/2017-regional-refugee-migrant-responseplan-europe-january-december-2017.html. Accessed 6 Feb 2017

7. Migration Policy Centre (MPC). Migration Policy Centre (MPC) [Internet]. 2015. Available from: http://www.migrationpolicycentre.eu/

8. United Nations High Commissioner for Refugees [UNHCR]. Serbia Response Plan [Internet]. 2017. Available from: http://www.unhcr.rs/media/docs/2017/januar/RRMRP-Serbia.pdf

9. United Nations High Commissioner for Refugees. Serbia Fact Sheet [Internet]. 2020. Available from: https://reliefweb.int/report/serbia/unhcr-serbia-fact-sheet-january-2020

10. Bhugra D. Review article Migration and mental health. Acta Psychiatr Scand [Internet]. 2004;109(4):243-58. Available from: http://doi.wiley.com/10.1046/j.0001-690X.2003.00246.x

11. World Health Organization, WHO EURO Regional Committee for Europe. Strategy and action plan for refugee and migrant health in the WHO European Region. In 66th SESSION, Copenhagen, Denmark, 12-15 September; 2016.

12. Gerritsen A a M, Bramsen I, Devillé W, van Willigen LHM, Hovens JE, van der Ploeg HM. Physical and mental health of Afghan, Iranian and Somali asylum seekers and refugees living in the Netherlands. Soc Psychiatry Psychiatr Epidemiol [Internet]. 2006 Jan [cited 2014 Aug 27];41(1):18-26. Available from: http://www.ncbi.nlm.nih.gov/pubmed/16341619

13. Carswell K, Blackburn P, Barker C. The Relationship Between Trauma, Post-Migration Problems and the Psychological Well-Being of Refugees and Asylum Seekers. Int J Soc Psychiatry [Internet]. 
2009 Nov 19 [cited 2014 Aug 27];57(2):107-19. Available from: http://isp.sagepub.com/cgi/doi/10.1177/0020764009105699

14. Vukčević Marković M, Živanović M, Bjekić J. Post-Migration Living Difficulties and Mental Health in Refugees and Asylum Seekers in Serbia. Polit Psychol - J Polit Psychol. 2019;1:32-45.

15. Cantekin D, Gençöz T. Mental Health of Syrian Asylum Seekers in Turkey: The Role of Pre-Migration and Post-Migration Risk Factors. J Soc Clin Psychol [Internet]. 2017;36(10):835-59. Available from: http://ezproxy.fiu.edu/login?url=https://search-proquestcom.ezproxy.fiu.edu/docview/1981731313?accountid=10901

16. Hallas P, Hansen AR, Stæhr MA, Munk-Andersen E, Jorgensen HL. Length of stay in asylum centres and mental health in asylum seekers: A retrospective study from Denmark. BMC Public Health. 2007;7:1-6.

17. Bogic M, Ajdukovic D, Bremner S, Franciskovic T, Galeazzi GM, Kucukalic A, et al. Factors associated with mental disorders in longsettled war refugees: Refugees from the former Yugoslavia in Germany, Italy and the UK. Br J Psychiatry. 2012;200(3):216-23.

18. Bogic M, Njoku A, Priebe S. Long-term mental health of war-refugees: a systematic literature review. BMC Int Health Hum Rights. 2015;15(1).

19. Vukčević M, Momirović J, Purić D. Adaptation of Harvard Trauma Questionnaire for working with refugees and asylum seekers in Serbia. Psihologija. 2016;49(3):277-99.

20. Purić D, Vukčević Marković M. Development and validation of the Stressful Experiences in Transit Questionnaire (SET-Q) and its Short Form (SET-SF). Eur J Psychotraumatol [Internet]. 2019;10(1):1-11. Available from: https://doi.org/10.1080/20008198.2019.1611091

21. Steel Z, Chey T, Silove D, Marnane C, Bryant RA, Van Ommeren M. Association of torture and other potentially traumatic events with mental health outcomes among populations exposed to mass conflict and displacement: A systematic review and meta-analysis. JAMA J Am Med Assoc. 2009;302(5):537-49.

22. Ventriglio A, Bhugra D. Migration, trauma and resilience. In: M S$\mathrm{O}$, editor. Trauma and migration. Springer International Publishing Switzerland; 2015. p. 69-79.

23. Bustamante LHU, Cerqueira RO, Leclerc E, Brietzke E. Stress, trauma, and posttraumatic stress disorder in migrants: a comprehensive review. Rev Bras Psiquiatr. 2018;40:220-5.

24. Bhugra D, Becker MA. Migration, cultural bereavement and cultural identity. World Psychiatry. 2005;4:18-24.

25. Pantelidou S, J CTK. Culture shock and social support: a survey of Greek migrant students. Soc Psychiatry Psychiatr Epidemiol. 2006;41(10):771-81.

26. Berry JW. Acculturation and identity. In: D B, KS B, editors. Textbook of cultural psychiatry. Cambridge University Press, Cambridge; 2007. p. 169-78. 
27. Beltran RO, Llewellyn GM, Silove D. Clinicians' understanding of International Statistical Classification of Diseases and Related Health Problems, 10th Revision diagnostic criteria: F62.0 enduring personality change after catastrophic experience. Compr Psychiatr. 2008;49:593-602.

28. Vidyanidhi K, Sudhir MP. Interpersonal sensitivity and dysfunctional cognitions in social anxiety and depression. Asian J Psychiatr. 2009;2(1):25-8.

29. Nickerson A, Priebe S, A BR, Morina N. Mechanisms of Psychological Distress following War in the Former Yugoslavia: The Role of Interpersonal Sensitivity. BMC Psychiatry. 2014;14(106).

30. Brooks R, Silove D, Steel Z, Steel CB, Rees S. Explosive anger in postconflict Timor Leste: interaction of socio-economic disadvantage and past human rights-related trauma. J Affect Disord. 2011;131:268-76.

31. Vukčević Marković M, Bjekić J. Methods and ethics in refugee research. In: Hamburger A, Hancheva C, Ozcurumez S, Scher C, Stanković B, Tutnjević S, editors. Forced Migration and Social Trauma. London and New York: Routledge; 2019.

32. World Health Organisation. Policy brief on migration and health: mental health care for refugees. 2015.

33. World Health Organization. Migration and health: Key Issues [Internet]. 2019. Available from: http://www.euro.who.int/en/health-topics/health-determinants/migration-and-health/migrant-health-in-theeuropean-region/migration-and-health-key-issues

34. Hollander AC, Dal H, Lewis G, Magnusson C, Kirkbride JB, Dalman C. Refugee migration and risk of schizophrenia and other non-affective psychoses: cohort study of 1.3 million people in Sweden. BMJ. 2016;352(i1030).

35. Fazel M, Wheeler J, Danesh J. Prevalence of serious mental disorder in 7000 refugees resettled in western countries: a systematic review. Lancet. 2005;365(9467):1309-14.

36. Slewa-Younan S, Uribe Guajardo MG, Heriseanu A, Hasan T. Systematic Review of Post-traumatic Stress Disorder and Depression Amongst Iraqi Refugees Located in Western Countries. J Immigr Minor Heal. 2015;17(4):1231-9.

37. Lichtenthal WG, Nilsson M, Kissane DW, Breitbart W, Kacel E, Jones EC, et al. Underutilization of mental health services among bereaved caregivers with prolonged grief disorder. Psychiatr Serv. 2011;62(10):1225-9.

38. Pejuskovic B, Lecic Tosevski D, Toskovic O. Longitudinal study of posttraumatic stress disorder in the community - risk and recovery factors. J Nerv Ment Dis. 2017;205(2):77-82.

39. Lecic-Tosevski D, Pejuskovic B, Miladinovic T, Toskovic O, Priebe S. PTSD in Serbian community - seven years after trauma exposure. 
J Nerv Ment Dis. 2013;201(12):1040-4.

40. Kolltveit S, Lange-Nielsen II, Thabet AA, Dyregrov A, Pallesen S, Johnsen TB, et al. Risk factors for PTSD, anxiety, and depression among adolescents in Gaza. J Traum Stress. 2012;25:164-70.

41. Tural U, Onder E, Aker T. Effect of depression on recovery from PTSD. Community Ment Heal J. 2012;48:161-6.

42. Atwoli L, Stein DJ, Koenen KC, McLaughlin KA. Epidemiology of posttraumatic stress disorder: prevalence, correlates and consequences. Curr Opin Psychiatry. 2015;28:(4):307-11.

43. Alpak G, Unal A, Bulbul F, Sagaltici E, Bez Y, Altindag A, et al. Post-traumatic stress disorder among Syrian refugees in Turkey: a cross-sectional study. Int J Psychiatry Clin Pr. 2015;19(1):45-50.

44. Firenze A, Aleo N, Ferrara C, Maranto M, La Cascia C, Restivo V. The occurrence of diseases and related factors in a center for asylum seekers in Italy. Zdr Varst. 2016;55(1):21-8.

45. Gupta M. Review of somatic symptoms in post-traumatic stress disorder. Int Rev Psychiatry. 2013;25(1):86-99.

46. Hitnin DE, Hinton S, Loeum RJR, Pich V, Pollack MH. The'multiplex model of somatic symptoms: application to tinnitus among traumatized Cambodian refugees. Tanscult Psychiatry. 2008;45(2):287-317.

47. Kruse J, Joksimovic L, Cavka M, Woller W, Schmitz N. Effects of trauma-focused psychotherapy upon war refugees. J Trauma Stress. 2009;22(6):585-92.

48. Kroll J, Yusuf AI, Fujiwara K. Psychosis, PTSD, and depression in Somali refugees in Minnesota. Soc Psychiatry Psychiatr Epidemiol. 2001;46(6):481-93.

49. Fisher HL, Jones PB, Fearon P, Craig TK, Dazzan P, Morgan K. The varying impact of type, timing and frequency of exposure to childhood adversity on its association with adult psychotic disorder. Psychol Med. 2010;40(12):1967-78.

50. Vukčević M, Dobrić J, Purić D. Mental health of asylum seekers in Serbia. Serbia, Belgrade: UNHCR; 2014.

51. Vukčević Marković M, Gašić J, Bjekić J. Refugees' Mental Health. Serbia, Belgrade: Psychosocial Innovation Network; 2017.

52. Vukčević Marković M, Stanković I, Bjekić J. Psychological wellbeing of refugees in Serbia. Serbia, Belgrade: Psychosocial Innovation Network; 2018.

53. Vukčević Marković M, Bobić A, Bjekić J. Psychological Well-being of Refugees and Asylum seekers in Serbia. Serbia, Belgrade: Psychosocial Innovation Network; 2019.

54. Bjekić J, Vukčević Marković M. Towards an integrative multisectoral approach in provision of mental health and psychosocial support services [Internet]. 2019. Available from: http://www.euro.who.int/_data/assets/pdf_file/0005/422195/MIGNewsletter-December-2019.pdf\#page $=9$

55. Laban CJ, Gernaat HBPE, Komproe IH, de Jong JTVM. Prevalence 
and predictors of health service use among Iraqi asylum seekers in the Netherlands. Soc Psychiatry Psychiatr Epidemiol. 2007;42:837-44.

56. Acarturk C, Konuk E, Cetinkaya M, Senay I, Sijbrandij M, Cuijpers $\mathrm{P}$, et al. EMDR for Syrian refugees with posttraumatic stress disorder symptoms: Results of a pilot randomized controlled trial. Eur J Psychotraumatol. 2015;6(1).

57. Stammel N, Knaevelsrud C, Katrin Schock L, Walther L, Wenk-Ansohn M, Böttche M. Multidisciplinary treatment for traumatized refugees in a naturalistic setting: Symptom courses and predictors. Eur J Psychotraumatol. 2017;8(2).

58. Bjekić J, Vukćević Marković M, Todorović N, Vračević M. Mental health of refugees and migrants. Research report. Serbia, Belgrade: Red Cross Serbia. 2019.

59. Vukćević Marković M, Stojadinović I, Živanović M, Bjekić J. Towards the improvement of protection of mental health of refugees in Serbia. Serbia, Belgrade: Psychosocial Innovation Network; 2019.

60. Schock K, Rosner R, Knaevelsrud C. Impact of asylum interviews on the mental health of traumatized asylum seekers. Eur J Psychotraumatol. 2015;6:1-10.

61. Jakobsen M, Ashley M, Demott M, Wentzel-larsen T. The impact of the asylum process on mental health: a longitudinal study of unaccompanied refugee minors in Norway. BMJ Open. 2017;7:1-8.

62. Svetozarević S, Vukčević Marković M, Pejušković B, Simonović P. Guidance on Protection and Improvement of Mental Health of Refugees, Asylum Seekers, and Migrants in Serbia. World Health Organization; 2019.

Doc. dr Bojana PEJUŠKOVIĆ, Institut za mentalno zdravlje, Beograd, Medicinski fakultet Univerzitet u Beogradu, Beograd, Srbija

Bojana PEJUSKOVIC, MD, PhD, Associate Professor, Institute of Mental Health, Belgrade University School of Medicine, Belgrade, Serbia

E-mail: bpejuskovic@hotmail.com 